DOI: 10.18778/2084-140X.08.20

\title{
Zofia A. Brzozowska, MirosŁaw J. Leszka, Maria Lekapene, Empress of the Bulgarians. Neither a Saint nor a Malefactress, translated by M. MA- JER, A. MęKARski, M. ZYtka, Łódź University Press, Jagiellonian University Press, Łódź-Kraków 2017 [= Byzantina Lodziensia, 36], pp. VII, 226.
}

In the latest publication in the series "Byzantina Lodziensia” (published since 1997 and fundamental for the development of Byzantine studies in Poland) the authors undertook the difficult task of writing a biography of Maria Lekapena, one of the most interesting and mysterious Bulgarian and Byzantine political figures of the first half of the $10^{\text {th }}$ century. Both Mirosław J. Leszka, an expert in the political history of medieval Bulgaria (recently: Simeon Veliki $i$ Vizantija, Sofia 2017) and Zofia A. Brzozowska (translator and editor of Rus' literature, e.g. Święta księżna kijowska Olga. Wybór tekstów źródłowych, Łódź 2014) are researchers who are perfectly prepared to meet this objective.

Maria Lekapena, daughter of Christoforus, and granddaughter of the great Emperor Romanos, has long been popular with researchers due to her marriage to the Bulgarian Tsar Peter. However, a closer look reveals increasing problems with a small amount of source data. On many, even basic issues (such as when she lived: born 907/915 - died before 963, perhaps in the early 960s; the number of children and their gender), the authors of the biography had to take their own stand. It is always relevant and supported according to the highest scholarly standards. However, on such controversial issues as Maria's personal political influence on Bulgarian-Byzantine relations, consensus will not be reached for a long time.

The treatise consists of eight chapters. The first one presents a synthesis of the source characteristics, while the remaining seven are a reconstruction of Maria's biography against a broad comparative background (especially in the area of politics and the political system: Mirosław J. Leszka). The authors have meticulously collected all source references, both literary and, which is worth emphasizing, sygillographic. Occasionally they were forced to reason ex silentio, but they always did so with great caution and prudence. Due to the silence of written sources in many aspects, undoubtedly a little mysterious, archaeological sources proved to be useful. Discoveries in the field of material culture in the Preslav region confirmed the influence of Byzantine women's fashion on Bulgarian aristocrats (dresses, jewelry), which can undoubtedly be attributed to the activity of Maria's court. On the other hand, the lack of archaeological evidence confirms the silence of written sources about the possible foundation and charity activities of the Tsaritsa. This way, two categories of sources confirm a certain element of her life, which is also controversial, given that this type of activity was a widely recognized tradition in the case of the Byzantine empresses, and was zealously imitated, for example, by the Kiev Duchesses. The above examples show how difficult a task (one that requires sensitivity, intuition and, at the same time, caution in dealing with the sources) the researchers had to face in order to uncover the life of Maria Lekapena, certainly extraordinary but hidden in the shadow.

A particularly valuable part of the book is the Appendix (p. 155-170). It contains an annotated translation of the so-called second edition of the Hellenic and Roman Chronicle, written in Rus' in the first half of the $15^{\text {th }}$ century. The text, based on both Slavic historiography (Rus' and Bulgarian) and Slavic translations of Byzantine historiography, provides information about the Tsar's family. Zofia Brzozowska not only presents a translation with an exhaustive philological and historical commentary, but also carefully describes the manuscript tradition of the relic, includes the codicological characteristics and the original text with the source apparatus. Given that editions of Slavic texts continue to be rare on the Polish publishing market, the work of the author should be particularly appreciated. 
The bibliography and footnotes have been compiled in accordance with the standard of the publishing series and meet all substantive requirements. The bibliography has been prepared very carefully, divided into sources and studies. It is very extensive and contains many works also from outside the English-speaking scholarly milieu (p. 170-200). As a result, the overall achievements of European Byzantine studies (especially the Bulgarian ones, as is natural in this case, but also Polish) have been noticed and appreciated. The Indices (p. 201-212) and the illustrations (p. 213-220) only attest to the care taken in releasing the work.

A separate point of interest is the linguistic editing and translation by Marek Majer. Translation is a form of art and, as is well known, involves a great deal of responsibility on the part of the translator. Marek Majer, who translated a significant part of the book and supervised the editing, has done an excellent job. The standardization of the translation of medieval Greek, Latin and Slavic terminology, while maintaining the lightness and clarity of style (the text reads well, the narrative is fast-paced, there are even appropriate native English proverbs in place of Polish ones), is a task that requires great skill, knowledge and talent. From the point of view of Polish Byzantine studies, good translation is of fundamental importance for the reception in the world's scholarly community. Of course by now the Łódź center has made a significant contribution in this respect to the undisputed successes (e.g. a marked increase in the representation of Polish literature in the bibliography of "Byzantinische Zeitschrift", a world-famous journal, or the quotability of the sister periodical "Studia Ceranea" even in publications on material culture that are not directly related to Byzantine studies ${ }^{1}$ ).

Therefore, there is no doubt that the reviewed publication meets all conditions both on the substantive and editorial level to participate in the international scholarly debate on equal terms.

\section{BIBLIOGRAPHY}

Textile Terminologies from the Orient to the Mediterranean and Europe, 1000 BC to 1000 AD, ed. S. GASPA, C. Michel, M.-L. Nosch, Lincoln 2017.

\section{Anna Kotłowska (Poznań)*}

\footnotetext{
${ }^{1} \mathrm{Cf}$. Textile Terminologies from the Orient to the Mediterranean and Europe, 1000 BC to $1000 A D$, ed. S. GASPA, C. Michel, M.-L. Nosch, Lincoln 2017.

* Uniwersytet im. Adama Mickiewicza w Poznaniu, Wydział Historyczny, Instytut Historii
}

DOI: 10.18778/2084-140X.08.21

Лев ХиросфАкт, Сочинения, перевод с греческого, подготовка издания,
комментарии, вступительная статья Т.А. Сениной (монахини Кассии)
[LEо СногоSPHAктES, Works, translated from Greek and edited with a com-
mentary and introduction by T.A. SeNINA (nun Kassia)], Алетейя, Санкт-Пе-
тербург 2017 [= Новая византийская библиотека. Источники], pp. 279.

$\mathrm{L}$ eo Choirosphaktes (845/850 - bef. 920) - the author of the works translated and published by Tat'jana Anatol'evna Senina in the volume under review ${ }^{1}$ - hailed from the Byzan-

\footnotetext{
${ }^{1}$ Beside the book under review, the scholarly output of Tat'jana A. Senina includes editions and studies such as: Св. КАССИЯ КОНСТАНТИНОПОЛЬСКАЯ, Гимны, каноны, эпиграммы [Sт. KASsia оF CoN-
}

StAntinople, Hymns, Canons, Epigrams] / Татьяна Сенина, Кассия Константинопольская: жизнь и творчество [St. Kassia of Constantinople: Life and Works], Санкт-Петербург 2015 [= LL.SB]; Лев МАТЕМАТИК И ФИЛОСОФ, Сочинения [LEO ТнЕ MATHematician and Philosopher, Works], trans. et ed. Т.А. СЕнинА, Санкт-Петербург 2017 [= НВБ.И]; Эллинизм в Византии IX века [Hellenism in $9^{\text {th }}$-Century Byzantium], Санкт-Петербург 2018 [= НВБ.И]; 